\title{
СРАВНИТЕЛЬНЫЙ АНАЛИЗ ЭНДОФИТНЫХ БАКТЕРИЙ РАЗНЫХ СОРТОВ КАРТОФЕЛЯ
}

\begin{abstract}
COMPARATIVE ANALYSIS
OF ENDOPHYTIC BACTERIA IN FIVE VARIETIES OF POTATO

\section{A. Tuama \\ Z. Stasecski}

N. Karamova

Summary. The article presents the results of isolation and characteristics of endophytic bacteria from five varieties of seed potato plants obtained from different geographic zones. Of the 49 isolates, the most were found in plant roots, $61 \%$ of the bacteria are spore-forming. The main number of isolates $(71 \%)$ are Gram-positive bacteria. The isolated endophytes belong to five genera, among which are dominated by representatives of the genus Bacillus. Differences in the quantitative and species composition of endophytes found in plants of different potato varieties have been established.
\end{abstract}

Keywords: endophytic bacteria, potato, biodiversity, ecological adaptation.

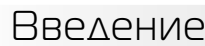

$\boldsymbol{9}$ ндофитными принято называть факультативно или лблигатно симбиотические микроорганизмы, которые имеют способность к заселению внутренних тканей растений $[29,16]$, при этом не оказывая на них никакого вредного воздействия [17]. Более того, результаты многих исследований свидетельствуют о том, что эндофитная микрофлора благотворно влияют на жизнедеятельность хозяев. Например, они могут улучшать фосфорное и азотное питание растений, продуцировать фитогормоны, витамины, регулировать осмотическое давление и работу устьиц, участвовать в модификации развития корневой системы растений и повышать их устойчивость к стрессам $[6$, 13]. Эндофиты также могут проявлять выраженную антагонистическую активность в отношении различных фитопатогенных микроорганизмов. Данные факты позволяют рассматривать эндофитные микроорганизмы в качестве перспективных кандидатов для стимуляции роста растений и биологического контроля фито-
Туама Аммар Аднан

Aспирант, ФГАОУ ВО «Казанский (Приволжский) федеральный университет» ammartuama02@gmail.com

Карамова Назира Сунагатовна

К.б.н., дочент, ФГАОУ ВО «Казанский (Приволжский) федеральный университет» nskaramova@mail.ru

Сташевски Зенон

К.б.н., в.н.С., ТатНИИСХ - обособленное структурное подразделение ФИЦ «Казанский научный иентр Российской академии наук» zenons@bk.ru

Аннотация. В статье представлены результаты выделения и характеристики эндофитных бактерий растений пяти сортов семенного картофеля, полученных из разных географических зон. Из 49 изолятов больше всего (19) было обнаружено в корнях растений, 61\% бактерий являются спорообразующими. Основное количество изолятов (71\%), являются бактериями с грамположительным морфотипом. Выделенные эндофиты являются представителями пяти родов, среди которых доминируют бактерии р. Bacillus. Установлены различия в количественном и видовом составе эндофитов, обнаруженных в растениях разных сортов картофеля.

Ключевые слова: эндофитные бактерии, картофель, биоразнообразие, экологическая адаптация.

патогенов [1]. Таким образом, одним из современных направлений агробиотехнологий является изучение свойств и возможности использования эндофитов для повышения эффективности производства продукции растениеводства [6].

Ежегодные биотические потери урожая, вызванные различными инфекционными болезнями, сорняками и вредителями, среди 5 экономически важных культур, таких как картофель, рис, кукуруза, хлопок и пшеница, составляют примерно 28-40\%. Наибольшие потери урожая показывает картофель (40\%), за которым следуют рис (38\%) и кукуруза (30\%). [26]. Картофель входит в перечень основных культур, которые определяет продовольственную безопасность нашей страны. Урожайность культуры (14 т/га) на территории России значительно отстаёт от среднемирового уровня (17 т/ га) из-за повышенной поражаемости фитопатогенами и вредителями [2]. Следует подчеркнуть, что изучение эндофитной микрофлоры картофеля представляет собой основу для более глубокого понимания меха- 
низмов взаимоотношений микроорганизмов и растений как при вегетативном росте, так и при хранении клубней, и, как следствие, разработки экологические безопасных подходов к регуляции жизнедеятельности и урожайности данной культуры.

\section{Цель работы}

Выделение и характеристика эндофитных бактерий из растений семенного картофеля пяти сортов.

\section{Материалы и метолы}

В работе использовались растения картофеля, выращенные из семян 5 сортов, полученных в разных географических зонах: Регги (Россия); Спринт (Германия); Гала (Германия); Ред Соня (Россия); Пикассо (Нидерланды). Сорт Регги был представлен растениями разных классов: Регги ПП-1 (первое полевое поколение), Регги ССЭ (Супер-супер элита), Регги СЭ (Супер-элита), Регги Э (Элита), остальные четыре сорта - растениями класса Элита (Э). Экспериментальные растения (по 5 образцов каждого сорта и класса) отбирались в период бутонизации растений.

Выделение эндофитных бактерий проводилось из разных частей растений (внутренних растительных тканей клубней, стеблей, листьев, корней) по методам, описанным в ранее опубликованных работах [7]. После поэтапной полной стерилизации поверхности растений с использованием раствора Tween 20,70\% раствор этанола, 5\% раствор гипохлорита натрия, стерильной дистиллированной воды снимали верхний слой каждой части стерильным скальпелем. Далее мелкие кусочки отдельных органов растений помещали на поверхность стерильной питательной среды (2\% агар (Лурия-Буртани, 2\% LA), содержащей 30 мкг/мл нистатина для подавления роста грибов, в чашках Петри. Чашки инкубировали в течение 48 часов при температуре $37^{\circ} \mathrm{C}$. Для получения чистых культур проводился многократный пересев колоний микроорганизмов на 2\% LA. Для оценки чистоты культуры бактерий проводили визуальный осмотр отдельных колоний, выросших на питательной среде, окраску клеток бактерий по Граму [4].

Идентификацию эндофитных бактерий осуществляли методом масс-спектрометрического анализа MALDITOF MS (Bruker Biotyper, Bruker Daltonik, Германия).

\section{Результаты и обсужление}

Из различных частей растений (корень, клубень, стебель, листья) картофеля сортов Регги (Россия); Спринт (Германия); Гала (Германия); Ред Соня (Россия); Пикассо (Нидерланды). всего было выделено 49 культи- вируемых изолятов эндофитных бактерий. При микроскопировании препаратов, приготовленных из культур эндофитных бактерий, нами установлено, что из 49 выделенных изолятов 30 (61\%) являются спорообразующими, а остальные 19 (39\%) - не образуют спор. Основное количество выделенных изолятов - 35 (71\%), являются бактериями с грамположительным и только 14 (29\%) - с грамотрицательным морфотипом. Доминирование грамположительных бактерий в эндосфере растений показано и в других работах, причем известно, что именно они способны синтезировать уникальные метаболиты, обладающие разнообразными эффектами: участвующие в стимуляции роста растений, биоконтроле патогенных микроорганизмов и защищающие своих хозяев от негативных стрессовых факторов $[28,12]$. Среди грамположительных энофитных бактерий наиболее известными продуцентами биологически активных веществ являются представители родов Bacillus и Streptomyces [27, 14].

Известно, что эндофитные микроорганизмы могут обитать в различных органах растений: в корнях, стеблях, листьях, некоторые виды были обнаружены в цветах, фруктах и семенах $[22,25,10,20,11]$. Эндофиты заселяют апопласт растений, локализуясь в клеточной стенке или межклеточном пространстве [21], а также могут перемещаться по просвету ксилемы [9].

Нами установлено, что основное количество эндофитных бактерий, у всех исследованных растений картофеля, содержится в корнях, а наименьшее количество бактерий - в листьях (Таблица 1). У растений сортов Гала, Ред Соня, Пикассо по два изолята эндофитных бактерий также было выделено из клубней.

Количественное распределение эндофитных микроорганизмов по разным органам растений согласуется с данными других исследователей $[15,31,19]$. Повышенное содержание эндофитных бактерий в корнях растений вероятно является следствием того, что клетки корней активно выделяют корневые экссудаты, которые содержат питательные вещества для микроорганизмов, способствуя образованию микробно-растительных ассоциаций внутри и вне корневых тканей, и поэтому именно корневая система является их основным местом проникновения микроорганизмов в организм растений [24].

На количество и разнообразие, экологическую адаптацию микрофлоры растений большое влияние оказывает окружающая среда. В настоящей работе выявлены различие в количественном составе эндофитов у сортов растений картофеля, полученных в различных географических зонах. Так, наибольшее количество эндофитных бактерий (10) было выделено из растений 
Таблица 1. Содержание изолятов эндофитных бактерий в корнях, стеблях, листьях и клубнях разных сортов картофеля

\begin{tabular}{|l|l|l|l|l|l|}
\multirow{2}{*}{ Сорт картофеля } & \multicolumn{2}{l|}{ Количество изолятов } & Ктебли & Листья & Клубни \\
\cline { 2 - 6 } & Всего & Корни & 3 & 1 & - \\
\hline Регги ПП1 & 7 & 3 & 2 & 1 & - \\
\hline Регги ССЭ & 7 & 3 & 2 & 2 & - \\
\hline Регги СЭ & 6 & 2 & 1 & 1 & - \\
\hline Регги Э & 4 & 2 & - & 1 & - \\
\hline Спринт Э & 2 & 1 & 2 & 1 & 2 \\
\hline Гала Э & 8 & 3 & - & 1 & 2 \\
\hline Ред Соня Э & 5 & 2 & 2 & 3 & 2 \\
\hline Пикассо Э & 10 & 3 & & \\
\hline
\end{tabular}

Таблица 2. Виды эндофитных бактерий, выделенные из разных сортов семенного картофеля

\begin{tabular}{|c|c|}
\hline Сорт картофеля & Вид эндофитных бактерий \\
\hline Регги ППП1 & $\begin{array}{l}\text { Bacillus megaterium (2), Enterobacter cloacae, Bacillus subtilis, Bacillus pumilus (2), } \\
\text { Staphylococcus warneri }\end{array}$ \\
\hline Регги ССЭ & $\begin{array}{l}\text { Bacillus pumilus, Enterobacter ludwigii (2), Bacillus mycoides, Bacillus subtilis, } \\
\text { Staphylococcus warneri, Bacillus simplex }\end{array}$ \\
\hline Регги СЭ & Enterobacter ludwigii, Bacillus pumilus (3), Lysinibacillus fusiformis, Bacillus mycoides \\
\hline Регги Э & $\begin{array}{l}\text { Bacillus weithenstephanensis, Bacillus mycoides, Staphylococcus warneri, Bacillus } \\
\text { horneckiae }\end{array}$ \\
\hline Спринт Э & Enterobacter cloacae, Enterobacter ludwigii \\
\hline Гала Э & $\begin{array}{l}\text { Enterobacter cloacae, Enterobacter hormaechei, Bacillus mojavensis, Bacillus pumilus, } \\
\text { Bacillus cereus, Enterobacter ludwigii (2), Bacillus megaterium }\end{array}$ \\
\hline Ред Соня Э & $\begin{array}{l}\text { Enterobacter ludwigii (2), Staphylococcus warneri, Bacillus cereus, Bacillus } \\
\text { weithenstephanensis }\end{array}$ \\
\hline Пикассо Э & $\begin{array}{l}\text { Bacillus thuringiensis, Acinetobacter pittii, Bacillus subtilis (4), Acinetobacter } \\
\text { baumannii, Staphylococcus warneri, Bacillus mojavensis, Bacillus pumilus }\end{array}$ \\
\hline
\end{tabular}

картофеля сорта Пикассо, семена которого были получены в Нидерландах (Таблица 1). Известно, что в Нидерландах интенсивно развивается семеноводство и производство экологически чистых продуктов. Эта страна также занимает второе место по выращиванию и экспорту семенного картофеля по всему миру [3]. Возможно, что благоприятные агротехнические условия и соблюдение оптимального баланса микроорганизмов в агробиоценозах, объясняют разнообразие бактерий, выделенной из растений сорта Пикассо.

Эндофитная микробиота характеризуется большим разнообразием - эндосимбионтами растений могут быть микроорганизмы разных групп: представители более, чем 200 родов 16 фил. Результаты исследований по анализу таксономической принадлежности эндофитных прокариот показывают, что в основном они являются представителями следующих фил: Proteobacteria, включая а-, $\beta$ - and $\gamma^{-}$Proteobacteria (54\%), Actinobacteria (20\%), Firmicutes (16\%), и Bacteroidetes
$(6 \%)[16,18]$. Следует подчеркнуть, что формирование микробиоты не происходит спонтанно, растения производят отбор определенных видов микроорганизмов. Об этом свидетельствуют данные по оценке биоразнообразия микроорганизмов некоторых культурных растений [8, 1]. Например, в работе [23] показано, что в микробиоме картофеля доминировали представители р. Enterobacter, Pseudomonas и Stenotrophomonas из филы Proteobacteria. Высокая специфичность эндофитного бактериального сообщества картофеля определяется разными факторами, включая стадия роста, физиологическое состояние растения и т.п. [30].

Идентификация изолятов эндофитных бактерий выделенных из сортов картофеля Спринт, Гала, Ред Соня, Пикассо, Регги позволила установить, что они являются представителями следующих родов: Lysinibacillus (L. fusiformis), Bacillus (B. megaterium, $B$. subtilis, B. pumilus, $B$. mycoides, B. simplex, $B$. weithenstephanensis, B. horneckiae, B. mojavensis, $B$. 
cereus, B. thuringiensis), Staphylococcus (S. warneri), Enterobacter (E. cloacae, E. ludwigii, E. hormaechei), Acinetobacter (A. pittii, A. baumannii), причем основная часть изолятов (28) принадлежат к роду Bacillus (Таблица 2).

Нами, на примере картофеля сорта Регги показано, что растения одного сорта, но разных классов имеют различия в составе эндофитной микрофлоры. При этом наибольшее количество (7) и разнообразие эндофитных бактерий приходится на первые годы размножения семенного картофеля (Таблицы 1, 2), что возможно связано с тем, что в первые годы жизни растению необходима дополнительная защита, которую ей обеспечивают полезные микроорганизмы. В растениях семенного картофеля более позднего срока размножения, начиная с класса Супер-элита обнаружено меньшее количество эндофитных бактерий.
Эндофитная микробиота каждого растения состоит из видов, проникших в растения из окружающей среды во время его вегетации, а также из микроорганизмов, полученных при вертикальном переносе от предыдущего поколения с семенами $[14,1]$.

Полученные нами результаты свидетельствуют в пользу мнения, что микробиота эндосферы в основном представлена микроорганизмами из окружающей среды $[18,14]$.

Дальнейшее исследование биологической активности выделенных нами изолятов эндофитных бактерий позволит выявить их уникальные особенности и использовать для разработки биопрепаратов с учетом особенностей разных сортов и географичеких зон выращивания для повышения урожайности и качества производства картофеля.

\section{ЛИТЕРАТУРА}

1. Васильева Е.Н., Ахтемова Г.А., Жуков В.А., Тихонович И.А. Эндофитные микроорганизмы в фундаментальных исследованиях и сельском хозяйстве// Экологическая генетика., 2019, т. 7(1), с.19-32.

2. Евстратова Л.П., Кузнецова Л.А., Николаева Е.В. Комплексная оценка урожайности и экологической адаптивности селекционного материала картофеля для использования в региональной технологии возделывания культуры // Известия Оренбургского государственного аграрного университета., 2020, № 6 (86), с. 85-90.

3. Зальцман В.А. Экономика и сельское хозяйство Нидерландов // Нивы России, 2016, № 8 (141), с. 1-4.

4. Канашкова Т.А., Адамович Т.Г., Каскевич Л.И. Микробиология с основами иммунологии - 3-е изд.- Минск: БГмУ, 2016. - 104 с.

5. Максимов И.В., Веселова С.В., Нужная Т.В., Сарварова Е.Р., Хайруллин Р.М. Стимулирующие рост растений бактерии в регуляции устойчивости растений к стрессовым факторам // Физиология растений., 2015, т. 62, № 6, с. 763-775.

6. Чеботарь В.К., Щербаков А.В., Щербакова Е.Н. Эндофитные бактерии как перспективный биотехнологический ресурс и их разнообразие // Сельскохозяйственная биология., 2015, т. 50, № 5, с. 648-654.

7. Anjum N., Chandra R. Endophytic bacteria: optimization of isolation procedure from various medicinal plants and their preliminary characterization // Asian Journal of Pharmaceutical and Clinical Research., 2015, v. 8(4), p. 233-238.

8. Berg G., Müller H., Zachow C., Opelt K., Scherwinski K., Tilcher R., Ulrich A., Hallmann J., Grosch R. and Sessitsch A. Endophytes: structural and functional diversity and biotechnological applications in control of plant pathogens // Экологическая генетика., 2008, т. VI, № 2, с. 17-26.

9. Compant S., Clément C. and Sessitsch A. Plant growth promoting bacteria in the rhizo- and endosphere of plants: their role, colonization, mechanisms involved and prospects for utilization // Soil Biology and Biochemistry., 2010, v.42(5), p. 669-678.

10. Compant S., Mitter B., Colli-Mull G., Gangle G. and Sessitsch A. Endophytes of grapevine flowers, berries, and seeds: identification of cultivable bacteria, comparison with other plant parts, and visualization of niches of colonization. // Microbial Ecology., 2011, v.62(1), p. 188-197.

11. de Melo-Pereira G.V., Magalhães K.T., Lorenzetii E.R., Souza T P., and Schwan R.F. A multiphasic approach for the identification of endophytic bacterial in strawberry fruit and their potential for plant growth promotion. // Microbial Ecology., 2012, v. 63(2), p. 405-417.

12. Ek-Ramos M.J., Gomez-Flores R, Orozco-Flores A.A., Rodríguez-Padilla C., González-Ochoa G. and Tamez-Guerra P. Bioactive Products From Plant-Endophytic Gram-Positive Bacteria // Frontiers in Microbiology., 2019, v.10 (463), doi: 10.3389/fmicb.2019.00463.

13. Fadiji A.E., Babalola 0.0. Elucidating mechanisms of endophytes used in plant protection and other bioactivities with multifunctional prospects. // Frontiers in Bioengineering and Biotechnology., 2020, v. 8, p. 467-487.

14. Frank, A., Saldierna-Guzmán, J., and Sha, J. Transmission of bacterial endophytes // Microorganisms., 2017, v. 5(4), p.70.

15. Gangwar M. Diversity and biopotential of endophytic actinomycetes from three medicinal plants in India. // African Journal of Microbiology Research., 2014, v. 8(2), p. 184-191.

16. Golinska P., Wypij M., Dnyaneshwar G.A., Dahm R.H.and Rai M. Endophytic actinobacteria of medicinal plants: diversity and bioactivity // Antonie van Leeuwenhoek., 2015, v.108, p. 267-289.

17. Hallmann J., Quadt-Hallmann A., Mahaffee W.F. and Kloepper J.W. Bacterial endophytes in agricultural crops // Can. J. Microbiol., 1997, v. 43, p. 895-914.

18. Hardoim P.R., Hardoim C.C., van Overbeek L.S., van Elsas J.D., Dynamics of seed-borne rice endophytes on early plant growth stages // Plos One., 2012, v.7(2), e30438, doi/org/10.1371/journal.pone.0030438. 
19. Harman G.E. and Uphof N. Symbiotic Root-Endophytic Soil Microbes Improve Crop Productivity and Provide Environmental Benefits // Hindawi Scientifica., 2019, v. 2019, Article ID9106395, 25 pages, doi.org/10.1155/2019/9106395.

20. Johnston-Monje D., and Raizada M.N. Conservation and diversity of seed associated endophytes in Zea across boundaries of evolution, ethnography and ecology // Plos One., 2011, v. 6(6), e20396, doi: 10.1371/journal.pone.0020396.

21. Koskimäki J., Pirttilä A.M., Ihantola, E.L., Halonen, 0., and Frank A.C. The intracellular scots pine shoot symbiont Methylobacterium extorquens DSM13060 aggregates around the host nucleus and encodes eukaryote-like proteins // MBio., 2015 v. 6(2), e00039-15, doi: 10.1128/mBio.00039-15.

22. Lodewyckx C., Vangronsveld J., Porteous F., Moore E.R.B., Taghavi S., Mezgeay M. et al. Endophytic bacteria and their potential applications. // Critical reviews in plant sciences., 2002, v.21(6), p. 583-606.

23. Marques J.M., da Silva T.F., Vollú R.E. et al. Bacterial endophytes of sweet potato tuberous roots affected by the plant genotype and growth stage //Applied Soil Ecology., 2015, v. 96, p. 273-281.

24. Paungfoo-Lonhienne C., Rentsch D., Robatzek S., Webb R.I., Sagulenko E., Näsholm T.et al. Turning the table: plants consume microbes as a source of nutrients // Plos One., 2010, v. 5(7), e11915, doi: 10.1371/journal.pone.0011915.

25. Partida-Martinez L.P., Heil M. The microbe-free plant: fact or artifact? // Frontiers in Plant Science., 2011, v.2 (100), p.1-16.

26. Qaim M. Genetically modified crops and global food security. // Genetically Modified Food and Global Welfare., 2011, v.10, p.29-54.

27. Reinhold-Hurek B., and Hurek T. Living inside plants: bacterial endophytes // Current opinion in plant biology., 2011, v. 14(4), p. $435-443$.

28. Ryan R.P., Germaine K., Franks A., Ryan D.J., and Dowling D.N. Bacterial endophytes: recent developments and applications. // FEMS Microbiology Letters., 2008, v.278(1), p.1-9.

29. Schulz, B., and Boyle C., What are endophytes. // Soil Biol., 2006, v. 9, p.1-13.

30. Sessitsch A., Reiter B.and Berg G. Endophytic bacterial communities of field grown potato plants and their plant growth promoting abilities // Canadian Journal of Microbiology., 2004, v.50(4), p.239-249.

31. Zhang Q., Jacquelinne J., Acuña J.A., Inostroza N.G., Mora M.L., Radic S., Michael J., Sadowsky M.J. and Jorquera M.A. Endophytic Bacterial Communities Associated with Roots and Leaves of Plants Growing in Chilean Extreme Environments // Scientific Reports., 2019, v. 9(1), p. 1-12.

(c) Туама Аммар Аднан ( ammartuama02@gmail.com ),

Карамова Назира Сунагатовна ( nskaramova@mail.ru ), Сташевски Зенон ( zenons@bk.ru ).

Журнал «Современная наука: актуальные проблемы теории и практики»

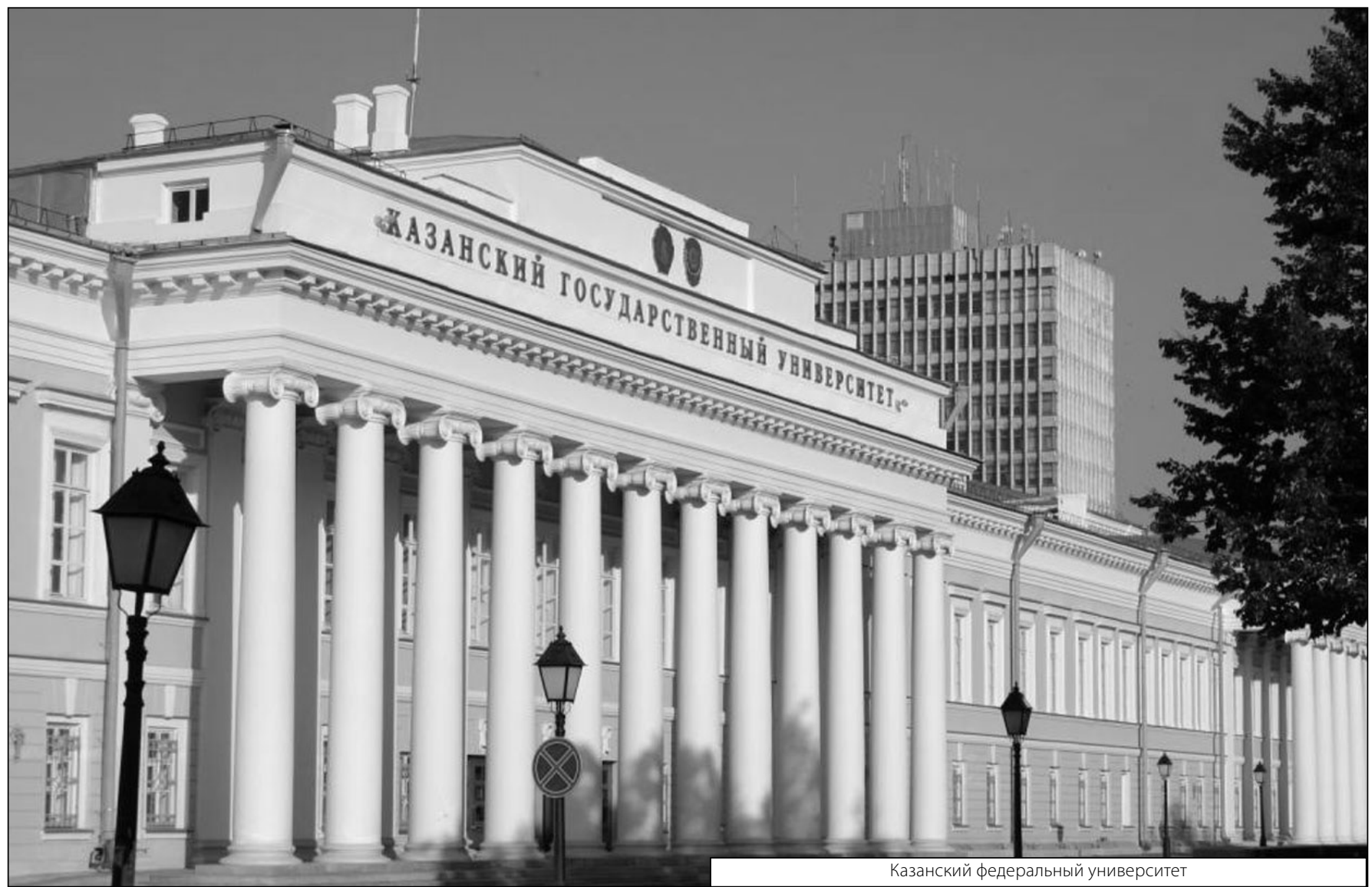

